\title{
Relationship between total body water and surface area in normal and obese subjects
}

\author{
R. HUME AND ELSPETH WEYERS \\ From the Department of Medicine, Southern General Hospital, Glasgow
}

SYNOPSIS Total body water was measured using tritium in 30 males and 30 females. It was found that total body water could be predicted from height and weight, and formulae for both males and females have been produced with multiple correlation coefficients (r) of 0.95 and 0.96 respectively. The predicted total body water was found to be very closely related to the predicted surface area giving correlation coefficients (r) for males and females of 0.997 and 0.985 respectively.

Total body water can be used for the prediction of lean body mass or fat-free body weight. This calculation is based on the assumption that fat is anhydrous and that fat-free tissue is approximately $73 \%$ water (Pace and Rathbun, 1945). This formula is said to make a valid first approximation for body fat in normal subjects (Moore, Olesen, McMurrey, Parker, Ball, and Boyden, 1963). Hume (1966) produced a formula for the easy prediction of lean body mass from height and weight based on the measurement of total body water using antipyrine space and the Pace and Rathbun equation (1945). The value of a measure of lean body mass as a point of reference for expressing the normal red cell volume has been clearly demonstrated (Muldowney, 1957; Hume and Goldberg, 1964). Recently, however, it has been shown by Retzlaff, Tauxe, Kiely, and Stroebel (1969) that the red cell volume can be equally well expressed in terms of predicted surface area as in terms of lean body mass in both normal and obese women. In this work the lean body mass was derived from the measurement of total body water using deuterium oxide $\left(\mathrm{D}_{2} \mathrm{O}\right)$. We have confirmed this observation indirectly by showing that total body water and therefore lean body mass is very closely correlated with surface area in normal and obese subjects and also that total body water can be readily predicted from height and weight.

\section{Methods}

\section{CLINICAL CASES}

Sixty ( 30 male and 30 female) volunteers were studied. They comprised the following clinical Received for publication 30 July 1970. groups: patients convalescing from myocardial $\rightarrow$ infarction (19 males, 5 females); cerebral vas- $\frac{7}{0}$ cular accident ( 3 males, 5 females); acute bronchitis ( 3 males, 2 females); peptic ulcer (1 male, 2 females); anxiety state ( 5 females); undiagnosed abdominal pain ( 2 males); disseminated sclerosis ( 2 females); primary obesity ( 2 males, 6 females); osteoarthritis (3 females). None had clinical evidence of fluid retention or malnutrition, conditions known to influence the relationship between total body water and total body weight. None was receiving diuretic therapy. Five males and 11 females were estimated to be more than $10 \%$ above the average weight for an adult. The ages of the males ranged from 35 years to 71 years with a mean of 54.5 years. The ages of the females ranged from 33 years to 84 years with a mean of 53.7 years.

\section{Height and weight}

The standing height in centimetres was measured without shoes. Total body weight in kilograms was estimated with the patient wearing only hospital bed attire.

The expected weight for each patient was obtained from the tables of average weights for adults produced by the Society of Actuaries (1959).

\section{Total body water}

Tritium space was measured by a modification of the method of Moore et al (1963). One millicurie of ${ }^{\circ}$ tritium was made up in $12 \mathrm{ml}$ of sterile saline and $\mathbb{D}$ autoclaved before administration. Ten $\mathrm{ml}$ of the solution was then injected intravenously from a calibrated $10 \mathrm{ml}$ disposable syringe. The remaining $\mathbb{D}$ $2 \mathrm{ml}$ was used for making the standard. Five $\mathrm{ml} \Omega$

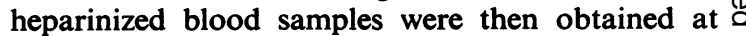




\begin{tabular}{|c|c|c|c|c|c|c|c|}
\hline $\begin{array}{l}\text { Subject } \\
\text { No. }\end{array}$ & $\begin{array}{l}\text { Age } \\
\text { (yr) }\end{array}$ & $\begin{array}{l}\text { Height } \\
(\mathrm{cm})\end{array}$ & $\begin{array}{l}\text { Weight } \\
(k g)\end{array}$ & $\begin{array}{l}\text { Measured } \\
\text { Total Body } \\
\text { Water }(I)\end{array}$ & $\begin{array}{l}\text { Predicted } \\
\text { Total Body } \\
\text { Water }(l)\end{array}$ & $\begin{array}{l}\text { Predicted } \\
\text { Surface } \\
\text { Area }(\text { sq } m)\end{array}$ & $\begin{array}{l}\text { Percentage } \\
\text { Overweight }\end{array}$ \\
\hline $\begin{array}{r}1 \\
2 \\
3 \\
4 \\
5 \\
6 \\
7 \\
8 \\
9 \\
10 \\
11 \\
12 \\
13 \\
14 \\
15 \\
16 \\
17 \\
18 \\
19 \\
20 \\
21 \\
22 \\
23 \\
24 \\
25 \\
26 \\
27 \\
28 \\
29 \\
30\end{array}$ & $\begin{array}{l}69 \\
59 \\
56 \\
60 \\
46 \\
52 \\
50 \\
53 \\
53 \\
52 \\
53 \\
69 \\
51 \\
40 \\
71 \\
64 \\
60 \\
57 \\
61 \\
57 \\
65 \\
48 \\
50 \\
55 \\
51 \\
35 \\
45 \\
54 \\
43 \\
55\end{array}$ & $\begin{array}{l}170 \cdot 2 \\
170 \cdot 2 \\
167 \cdot 6 \\
158 \cdot 8 \\
177 \cdot 8 \\
161 \cdot 3 \\
165 \cdot 1 \\
160 \cdot 0 \\
174 \cdot 0 \\
180 \cdot 3 \\
177 \cdot 8 \\
132 \cdot 1 \\
180 \cdot 3 \\
172 \cdot 7 \\
170 \cdot 2 \\
170 \cdot 2 \\
180 \cdot 3 \\
163 \cdot 5 \\
176 \cdot 5 \\
163 \cdot 5 \\
156 \cdot 2 \\
185 \cdot 4 \\
168 \cdot 9 \\
174 \cdot 0 \\
175 \cdot 3 \\
175 \cdot 3 \\
175 \cdot 3 \\
179 \cdot 1 \\
172 \cdot 7 \\
172 \cdot 7\end{array}$ & $\begin{array}{r}66 \cdot 4 \\
62 \cdot 7 \\
63 \cdot 6 \\
67 \cdot 3 \\
70 \cdot 0 \\
70 \cdot 9 \\
66 \cdot 4 \\
50 \cdot 0 \\
67 \cdot 3 \\
74 \cdot 5 \\
67 \cdot 0 \\
36 \cdot 4 \\
83 \cdot 6 \\
65 \cdot 9 \\
75 \cdot 0 \\
64 \cdot 1 \\
58 \cdot 2 \\
66 \cdot 8 \\
75 \cdot 0 \\
62 \cdot 1 \\
59 \cdot 1 \\
89 \cdot 1 \\
68 \cdot 9 \\
77 \cdot 3 \\
48 \cdot 6 \\
121 \cdot 8 \\
86 \cdot 4 \\
96 \cdot 3 \\
108 \cdot 6 \\
84 \cdot 3\end{array}$ & $\begin{array}{l}38 \cdot 9 \\
34 \cdot 4 \\
37 \cdot 8 \\
33 \cdot 2 \\
40 \cdot 8 \\
38 \cdot 0 \\
38 \cdot 3 \\
33 \cdot 5 \\
41 \cdot 8 \\
47 \cdot 8 \\
41 \cdot 9 \\
24 \cdot 3 \\
43 \cdot 7 \\
40 \cdot 7 \\
40 \cdot 7 \\
38 \cdot 4 \\
36 \cdot 6 \\
40 \cdot 1 \\
44 \cdot 9 \\
36 \cdot 9 \\
30 \cdot 9 \\
48 \cdot 8 \\
41 \cdot 0 \\
42 \cdot 7 \\
31 \cdot 3 \\
55 \cdot 5 \\
48 \cdot 7 \\
48 \cdot 8 \\
52 \cdot 2 \\
41 \cdot 8\end{array}$ & $\begin{array}{l}38 \cdot 8 \\
37 \cdot 7 \\
37 \cdot 5 \\
36 \cdot 9 \\
41 \cdot 4 \\
38 \cdot 4 \\
37 \cdot 9 \\
31 \cdot 9 \\
39 \cdot 8 \\
43 \cdot 2 \\
40 \cdot 5 \\
22 \cdot 5 \\
45 \cdot 9 \\
39 \cdot 2 \\
41 \cdot 7 \\
38 \cdot 2 \\
38 \cdot 3 \\
37 \cdot 7 \\
42 \cdot 6 \\
36 \cdot 3 \\
33 \cdot 9 \\
48 \cdot 5 \\
39 \cdot 3 \\
42 \cdot 8 \\
34 \cdot 1 \\
56 \cdot 3 \\
45 \cdot 8 \\
49 \cdot 5 \\
51 \cdot 9 \\
44 \cdot 6\end{array}$ & $\begin{array}{l}1 \cdot 78 \\
1 \cdot 78 \\
1 \cdot 71 \\
1 \cdot 70 \\
1 \cdot 87 \\
1 \cdot 75 \\
1 \cdot 73 \\
1 \cdot 50 \\
1 \cdot 81 \\
1.93 \\
1.83 \\
1 \cdot 14 \\
2.04 \\
1 \cdot 78 \\
1.86 \\
1 \cdot 74 \\
1.75 \\
1 \cdot 73 \\
1.91 \\
1.67 \\
1.58 \\
2 \cdot 14 \\
1.78 \\
1.92 \\
1 \cdot 58 \\
2.36 \\
2.03 \\
2 \cdot 16 \\
2.20 \\
1.99\end{array}$ & $\begin{array}{l}62.8 \\
12.6 \\
19.6 \\
45.0 \\
12.7\end{array}$ \\
\hline
\end{tabular}

Table I Results in males

\begin{tabular}{|c|c|c|c|c|c|c|c|}
\hline $\begin{array}{l}\text { Subject } \\
\text { No. }\end{array}$ & $\begin{array}{l}\text { Age } \\
(y r)\end{array}$ & $\begin{array}{l}\text { Height } \\
(\mathrm{cm})\end{array}$ & $\begin{array}{l}\text { Weight } \\
(k g)\end{array}$ & $\begin{array}{l}\text { Measured } \\
\text { Total Body } \\
\text { Water (I) }\end{array}$ & $\begin{array}{l}\text { Predicted } \\
\text { Total Body } \\
\text { Water }(l)\end{array}$ & $\begin{array}{l}\text { Predicted } \\
\text { Surface } \\
\text { Area }(s q \mathrm{~m})\end{array}$ & $\begin{array}{l}\text { Percentage } \\
\text { Overweight }\end{array}$ \\
\hline $\begin{array}{l}1 \\
2 \\
3 \\
4 \\
5 \\
6 \\
7 \\
8 \\
9 \\
10 \\
11 \\
12 \\
13 \\
14 \\
15 \\
16 \\
17 \\
18 \\
19 \\
20 \\
21 \\
22 \\
23 \\
24 \\
25 \\
26 \\
27 \\
28 \\
29 \\
30\end{array}$ & $\begin{array}{l}55 \\
65 \\
57 \\
84 \\
58 \\
58 \\
50 \\
68 \\
62 \\
54 \\
59 \\
41 \\
47 \\
43 \\
46 \\
66 \\
59 \\
48 \\
41 \\
57 \\
63 \\
35 \\
61 \\
33 \\
53 \\
56 \\
42 \\
54 \\
49 \\
49\end{array}$ & $\begin{array}{l}160.0 \\
157 \cdot 7 \\
162.6 \\
146 \cdot 1 \\
152 \cdot 4 \\
147 \cdot 3 \\
144 \cdot 8 \\
149 \cdot 9 \\
157 \cdot 5 \\
149.9 \\
154.9 \\
151 \cdot 1 \\
154 \cdot 9 \\
158 \cdot 8 \\
149.9 \\
161 \cdot 3 \\
154.9 \\
154.9 \\
157 \cdot 5 \\
153.7 \\
154.9 \\
158 \cdot 8 \\
157 \cdot 5 \\
170 \cdot 2 \\
161 \cdot 3 \\
170 \cdot 2 \\
167 \cdot 6 \\
152 \cdot 4 \\
156 \cdot 2 \\
160 \cdot 0\end{array}$ & $\begin{array}{r}42 \cdot 3 \\
60 \cdot 9 \\
48 \cdot 2 \\
36 \cdot 8 \\
35 \cdot 5 \\
32 \cdot 3 \\
57 \cdot 3 \\
62 \cdot 3 \\
56 \cdot 8 \\
40 \cdot 5 \\
39 \cdot 1 \\
45 \cdot 0 \\
40 \cdot 9 \\
62 \cdot 0 \\
55 \cdot 2 \\
62 \cdot 7 \\
45 \cdot 0 \\
57 \cdot 0 \\
53 \cdot 6 \\
81 \cdot 8 \\
100 \cdot 0 \\
90 \cdot 5 \\
105 \cdot 9 \\
93 \cdot 6 \\
96 \cdot 8 \\
102 \cdot 3 \\
108 \cdot 2 \\
84 \cdot 5 \\
67 \cdot 3 \\
76 \cdot 6\end{array}$ & $\begin{array}{l}28 \cdot 8 \\
30 \cdot 6 \\
30 \cdot 6 \\
21 \cdot 8 \\
23 \cdot 5 \\
21 \cdot 7 \\
26 \cdot 0 \\
26 \cdot 3 \\
27 \cdot 0 \\
22 \cdot 7 \\
26 \cdot 3 \\
26 \cdot 9 \\
23 \cdot 3 \\
31 \cdot 7 \\
27 \cdot 1 \\
29 \cdot 7 \\
25 \cdot 7 \\
27 \cdot 3 \\
30 \cdot 8 \\
30 \cdot 2 \\
38 \cdot 6 \\
36 \cdot 8 \\
46 \cdot 6 \\
36 \cdot 8 \\
36 \cdot 8 \\
56 \cdot 1 \\
41 \cdot 9 \\
33 \cdot 8 \\
31 \cdot 9 \\
37 \cdot 0\end{array}$ & $\begin{array}{l}26 \cdot 6 \\
30 \cdot 3 \\
29 \cdot 6 \\
21 \cdot 9 \\
23 \cdot 7 \\
21 \cdot 4 \\
25 \cdot 2 \\
27 \cdot 8 \\
29 \cdot 4 \\
23 \cdot 8 \\
25 \cdot 3 \\
25 \cdot 1 \\
25 \cdot 6 \\
30 \cdot 8 \\
26 \cdot 5 \\
31 \cdot 8 \\
26 \cdot 4 \\
28 \cdot 6 \\
28 \cdot 8 \\
32 \cdot 7 \\
36 \cdot 5 \\
36 \cdot 1 \\
38 \cdot 5 \\
40 \cdot 6 \\
38 \cdot 1 \\
42 \cdot 2 \\
42 \cdot 4 \\
32 \cdot 8 \\
30 \cdot 9 \\
33 \cdot 9\end{array}$ & $\begin{array}{l}1 \cdot 39 \\
1.61 \\
1.49 \\
1 \cdot 23 \\
1 \cdot 25 \\
1 \cdot 17 \\
1.48 \\
1.57 \\
1.57 \\
1.31 \\
1 \cdot 32 \\
1.38 \\
1.34 \\
1.63 \\
1.49 \\
1.66 \\
1.40 \\
1.55 \\
1.53 \\
1.80 \\
1.97 \\
1.92 \\
2.04 \\
2.04 \\
2.00 \\
2.12 \\
2.16 \\
1.81 \\
1.68 \\
1.80\end{array}$ & $\begin{array}{l}37 \cdot 2 \\
64 \cdot 5 \\
56 \cdot 6 \\
70 \cdot 5 \\
45 \cdot 3 \\
50 \cdot 3 \\
44 \cdot 5 \\
62 \cdot 2 \\
43 \cdot 2 \\
12 \cdot 9 \\
24 \cdot 1\end{array}$ \\
\hline
\end{tabular}

Table II Results in females 
two hours and three hours after injection from the opposite arm. Using hyamine as solute and modified Bray liquid scintillator the samples were made up as follows and counted for $\mathbf{1 0 0}$ minutes in a Packard tricarb liquid scintillation spectrometer.

Duplicate samples of $0.2 \mathrm{ml}$ plasma or $0.2 \mathrm{ml}$ 1/500 dilution of standard in deionized water plus $1.0 \mathrm{ml}$ hyamine were allowed to stand for at least 24 hours at $4^{\circ} \mathrm{C}$ in a refrigerator. Thereafter 10.0 $\mathrm{ml}$ modified Bray liquid scintillator was added and the samples were counted. Blanks were made up similarly using deionized water. None of the duplicated samples gave results which differed by more than $5 \%$.

\section{Lean body mass}

Lean body mass (L.B.M.) was calculated as L.B.M. $=\frac{\text { T.B.W. }}{1} \times \frac{100}{73}$, where T.B.W. is total body water.

\section{Surface area}

Surface area in square metres was calculated from the subject's height and weight by the formula of du Bois and du Bois (1916). Surface area $(\log A)=$ $\log \mathrm{W} \times 0.425+\log \mathrm{H} \times 0.725+1.8564$, where $\mathrm{W}=$ weight in kilograms and $\mathbf{H}=$ height in centimetres.

\section{Results}

The results are set out in Tables I and II.

\section{MALES (30)}

The linear regression of total body water in litres on height $(\mathrm{H})$ in centimetres and on weight $(\mathrm{W})$ in kilograms is

$0 \cdot 194786 \mathrm{H}+0 \cdot 296785 \mathrm{~W}-14 \cdot 012934$.

The correlation coefficient $(r)$ between height and weight was $0.547(\mathrm{P}<0.01)$ and between height and total body water was $0.711(\mathrm{P}<0.001)$ and between weight and total body water was $0.920(P<0.001)$, yielding a multiple correlation coefficient $(r)$ between total body water and height and weight of 0.953041 . The standard deviation of deviations from the regression is 2.094354 . The standard error of the estimate for the prediction of total body water for an individual male with height $\mathrm{H}_{0}$ and weight $\mathrm{W}_{0}$ is:

$$
2.094354 \sqrt{\begin{array}{l}
1.033333+0.000479\left(\mathrm{H}_{0}-170 \cdot 24333\right) \\
-0.000311\left(\mathrm{H}_{0}-170 \cdot 24333\right) \\
\times\left(\mathrm{W}_{0}-71 \cdot 78667\right) \\
+0.000169\left(\mathrm{~W}_{0}-71.78667\right)^{2} .
\end{array}}
$$

Thus the $95 \%$ confidence limit for the total body water for an individual male subject with height $\mathbf{H}_{0}$ and weight $\mathrm{W}_{0}$ is

$0 \cdot 194786 \mathrm{H}_{0}+0.296785 \mathrm{~W}_{0}-14.012934$ $\pm \mathrm{t} 27,5 \% \times$ (standard error).

FEMALES (30)

The linear regression of total body water in litres on height $(\mathrm{H})$ in centimetres and weight (W) in kilograms is $0 \cdot 344547 \mathrm{H}+0.183809 \mathrm{~W}-35 \cdot 270121$.

The correlation coefficient (r) between height and weight was $0.589(\mathrm{P}<0.001)$ and between height and total body water was $0.770(P<0.001)$ and between weight and total body water was 0.913 $(P<0.001)$, yielding a multiple correlation coefficient (r) between total body water and height and weight of 0.957135 . The standard deviation of deviations from the regression is 1.845256 . The standard error of the estimate for the prediction of total body water for an individual female with $\mathbf{H}_{\mathbf{0}}$ and $\mathrm{W}_{0}$ is:

$$
1.845256 \sqrt{\begin{array}{c}
1.033333+0.001315\left(\mathrm{H}_{0}-156.30667\right)^{2} \\
-0.000417\left(\mathrm{H}_{0}-156.30667\right) \\
\times\left(\mathrm{W}_{0}-64.69667\right) \\
+0.000095\left(\mathrm{~W}_{0}-64.69667\right)^{2}
\end{array}}
$$

Thus the $95 \%$ confidence limits for the total body water for an individual female subject with height $\mathrm{H}_{0}$ and weight $\mathrm{W}_{0}$ is

$0 \cdot 344546 \mathrm{H}_{0}+0 \cdot 183809 \mathrm{~W}_{0}-35 \cdot 270121$

$\pm{ }^{2} 27,5 \% \times$ (standard error).

Analysis of the male and female regression lines reveals that they are significantly different and that this is not due simply to a constant shift. The regression coefficients of weight are significantly different using $t$ tests $(t=3.52 ; d f=54 ; P<0.001)$.

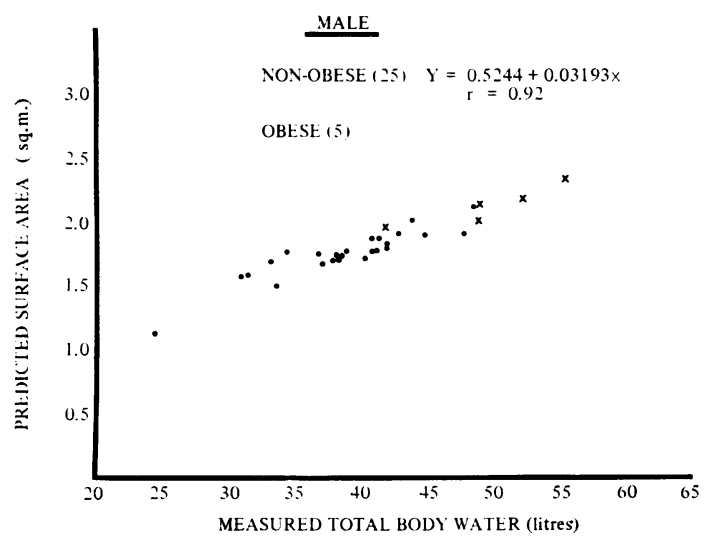

Fig. 1. The linear regression of predicted surface area on measured total body water in males. 


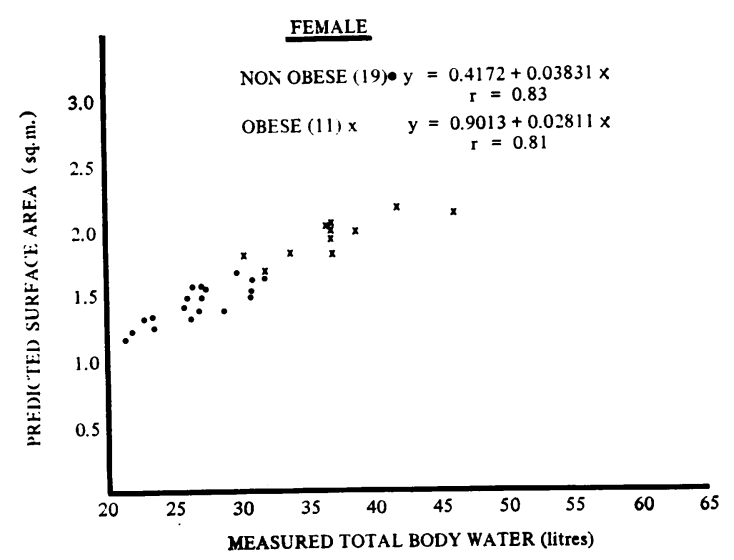

Fig. 2. The linear regression of predicted surface area on measured total body water in females.

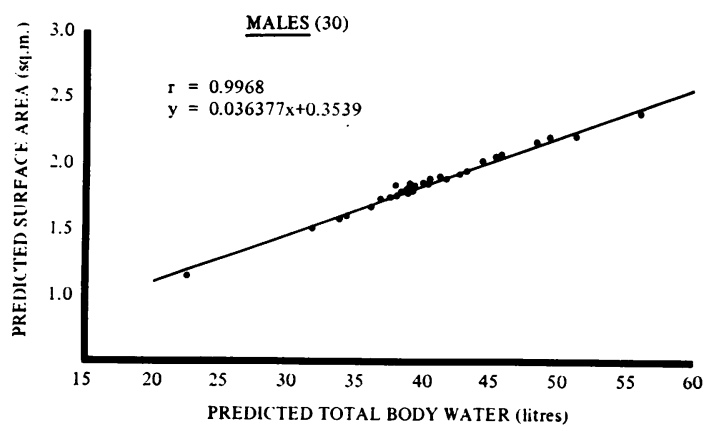

Fig. 3. The linear regression of predicted surface area on predicted total body water in males.

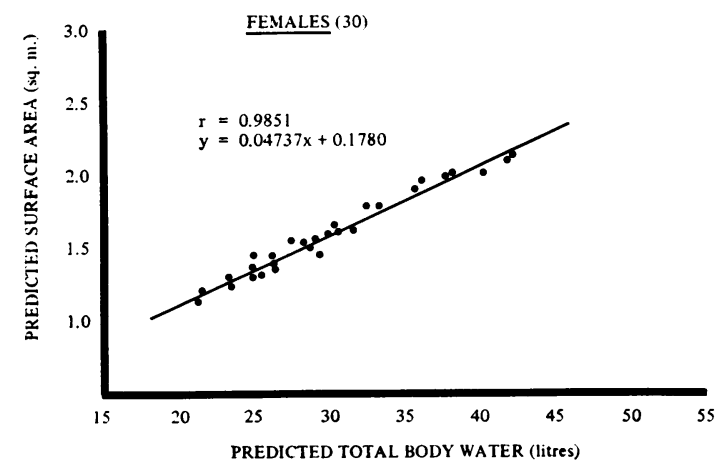

Fig. 4. The linear regression of predicted surface area on predicted total body water in females.
The relationship between the measured total body water and the predicted surface area for the 25 nonobese males is shown in Figure 1. The linear regression of the predicted surface area on measured total body water is $y=0.5244+0.03193 x$, and the correlation coefficient $(r)$ between measured total body water and predicted surface area is $0.9162(P<0.001)$. The five obese subjects did not deviate from this line.

The relationship between the measured total body water and the predicted surface area for the 19 nonobese females is shown in Figure 2. The linear regression of the predicted surface area on measured total body water is $y=0.4172+0.03831 x$, and the correlation coefficient ( $r$ ) between measured total body water and predicted surface area is 0.8260 (P < 0.001).

The relationship between the measured total body water and the predicted surface area for the 11 obese females is also shown in Figure 2. The linear regression of the predicted surface area on measured total body water is $y=0.9013+0.02811 x$, and the correlation coefficient ( $r$ ) between measured total body water and predicted surface area is $0.8134(\mathrm{P}<0.01)$.

The relationship between the predicted total body water and the predicted surface area in 30 males is shown in Figure 3. The linear regression of the predicted surface area on predicted total body water is $y=0.036377 x+0.3539$ and the correlation coefficient ( $r$ ) between predicted total body water and surface area is $0.9968(\mathrm{P}<0.001)$. The obese subjects did not deviate from this line.

The relationship for 30 females is shown in Figure 4. The linear regression of predicted surface area on predicted total body water is $y=0.04737 x+0 \cdot 1780$, and the correlation coefficient ( $r$ ) between these measurements is $0.9851(\mathrm{P}<0.001)$. These obese subjects did not deviate from this line.

\section{Discussion}

The results confirm the observation of Hume (1966) that total body water is closely related to height and weight in both males $(r=0.95)$ and females $(r=0.96)$ and that the relationship is equally satisfactory in both sexes for predicting total body water and indirectly lean body mass in an individual case. Hume found a less satisfactory correlation in females when using antipyrine space as a measure of total body water. The present study also reveals that the two formulae are different for the sexes and that this is mainly due to the relative contribution that weight makes to the relationship. This finding is in keeping with the observation that total body water relative to body weight is lower in females than in 
males (Moore et al, 1963). Although age is also an important factor in determining the relationship between body weight and total body water (Moore et al, 1963), as has been argued before (Hume, 1966), there seems little merit in introducing another factor when the correlation between height and weight and total body water is so close. In view of the age distribution of the individuals studied these formulae are applicable to those over the age of 16 years (Hume, 1967). However, it is not certain whether the formulae are applicable to individuals who are more than $180 \%$ of their average weight as calculated from the Society of Actuaries' tables (1959). The influence of weights greater than this are being investigated.

An unexpected finding was the very close correlation which exists between the predicted total body water and the predicted surface area for both sexes ( $r=0.997$ males; $r=0.985$ females) rendering these two formulae interchangeable for clinical practice. One of the limitations of the predicted total body water formulae is that in very obese subjects the increase in weight is due to a relatively anhydrous tissue and therefore the total body water and consequently lean body mass will be overpredicted. With the surface area formula, since the increase in weight in the obese subject is due to a tissue with a density less than 1 , it will therefore occupy a greater volume than if the increase in weight were due to lean tissue with a density of greater than 1. However, when the groups of patients studied are broken down into the obese and the non-obese, it can be seen that the correlation between the actual total body water and predicted surface area for the 19 non-obese females $(r=0.83)$ is of the same order as that for the 11 obese females $(\mathrm{r}=0.81)$ and that they are not a different population. Similarly, while there are only five obese males, it can be clearly seen that they do not differ in any way from the non-obese males. Therefore, within the fairly wide range of weights used in the present study, discrepancies due to weight are not likely to be important.

The clinical relevance of these observations is that in situations where predicted total body water or lean body mass is used as a point of reference, as for example in defining a normal red cell volume (Muldowney, 1957; Hume and Goldberg, 1964) or total body potassium (Hume, 1967), surface area will be equally suitable as a point of reference (Retzlaff et al, 1969), and similarly in situations where surface area is used, as in cardiac output, predicted lean body mass is equally suitable (Hume, 1970).

We are grateful to Miss Rosemary Dalton of the University Department of Epidemiology and Preventive Medicine for help with the statistical analysis.

\section{References}

Bois, D. du, and Bois, E. F. du (1916). A formula to estimate the approximate surface area if height and weight be known. Arch. intern. Med., 17, 863-871.

Hume, R. (1966). Prediction of lean body mass from height and weight. J. clin. Path., 19, 389-391.

Hume, R. (1967). Polycythaemia. MD Thesis, Glasgow.

Hume, R. (1970). Relationship between cardiac output and lean body mass. (Unpublished observation.)

Hume, R., and Goldberg, A. (1964). Actual and predicted-normal red-cell and plasma volumes in primary and secondary polycythaemia. Clin. Sci., 26, 499-508.

Moore, F. D., Olesen, K. H., McMurrey, J. D., Parker, H. V., Ball, M. R., and Boyden, C. M. (1963). The Body Cell Mass and its Supporting Environment. Saunders, Philadelphia and London.

Muldowney, F. P. (1957). The relationship of total red cell mass to lean body mass in man. Clin. Sci., 16, 163-169.

Pace, N., and Rathbun, E. N. (1945). Studies on body composition. III The body water and chemically combined nitrogen content in relation to fat content. J. biol. Chem., 158, 685-691.

Retzlaff, J. A., Tauxe, W. N., Kiely, J. M., and Stroebel, C. F. (1969). Erythrocyte volume, plasma volume and lean body mass in adult men and women. Blood, 33, 649-661.

Society of Actuaries (1959). Build and Blood Pressure Study (Tables), Vol. 1, p. 16. So ziety of Actuaries, Chicago. 